\title{
Legal regulation of the family members' entrepreneurial activity and inheritance relations: law enforcement problems
}

\author{
Vladislav Vasilyevich Kudryashov ${ }^{1 *}$, Valentina Sergeevna Lepeshkina ${ }^{2}$, Irina Vladimirovna \\ Sazonova $^{2}$, Aleksandr Anatolevich Potkin ${ }^{3}$, and Viktor Anatolevich Altunin ${ }^{3}$ \\ ${ }^{1}$ Moscow State Regional University, Civil Law Department, Moscow, Russia \\ ${ }^{2}$ Moscow University for Industry and Finance "Synergy", Department of Law Disciplines, Moscow, \\ Russia \\ ${ }^{3}$ Moscow University of Finance and Law, Department of Civil Law Disciplines, Moscow, Russia
}

\begin{abstract}
The problem of transition in the line of business assets and obligations succession with regard to norms of civil, family and business law represents an important legal problem as for the matter of family business succession. Russian legislation does not determine the family business succession as a single entity, there exists no special regulation as well as the term "entrepreneurial succession". The doctrine gives a reasonable conclusion that "practices of the recent past reveal substantial problems of marital regimes legal regulation under a digital transformation of the economy". Inheriting different properties that can be collectively referred to sphere of entrepreneurial activity causes many problems of similar properties transition in the line of succession in the field of law enforcement. Determining particularities of legal regulation of inheritance relations complicated with business activities in order to ensure efficient regulation of succession to business assets and debts and as well to ensure law enforcement stability. The methodological base for the present scientific research is represented by the system of general scientific and specific scientific methods and research techniques, including a historical method, a logical method, a method of system analysis and research, a comparative legal method, a statistical method, a functional-structural method, methods of analysis and synthesis, a method of specification, an empirical and theoretical method, i.e. analogy, deduction. The authors suppose that in conditions of the world financial crisis complicated with consequences of the coronavirus pandemic small businesses are the most vulnerable, including family businesses. The authors believe that a modern lawyer must have systemic knowledge for efficient application of civil law, inheritance law, family law, entrepreneurial law on the basis of the convergence principle in law. The use of a rather broad methodological base allows determining essential properties of legal regulation of the family members' entrepreneurial activity and inheritance relations from the point of view of law enforcement problems resolution. As for particularities of inheritance regulations application, a joint-stock company is supposed to have certain mechanisms of the protection of its interests in terms of its shares
\end{abstract}

${ }^{*}$ Corresponding author: kudryashov.minfin@ya.ru 
inheritance. For example, it is possible to envisage the right of a private joint-stock company to discourage inclusion within its shareholders a new participant in line with a similar power of the limited liability companies.

Keywords: legal regulation, entrepreneurial activity, inheritance relations, family business

\section{Introduction}

In connection with serious social and political changes that Russia undergo in the 1990s of the 21 th century a command economy and strict public control are replaced by a market economy with its inherent system of economic incentives and certain constraints and prohibitions established by the federal law [1]. The authors should agree with the opinion as stated in the doctrine, that "in spite of the inheritance law' material nature of its main purpose is to protect the family's interests that is proved by the general rule of inheritance" [2]. In fact, family law regulations are aimed at protection of the family members' rights and interests, firstly their property rights, in particular, when applying the inheritance laws.

It is obvious that the interests of small business entities - that family businesses are also referred to - require particular protection, including in the framework of civil, entrepreneurial, family and corporate law. "Training of lawyers for business is currently performed on the basis of the complicatedly built system" [3].

World trends are such that for many countries' economy family business is an important social and legal phenomenon. However, in the Russian Federation there exists no legal basis to develop a family business. Meanwhile, the concept of family entrepreneurship is widely discussed within the domestic doctrine and finds itself scientifically and practically encouraged. The national science is currently inactive search of optimal ways to tackle social and economic problems, ensure respect of the citizens' rights guaranteed by the Constitution of the Russian Federation and federal law in an inheritance-law relationship [4].

The development of modern legal relationships encourages an increase of the number of contractual relations [5]. It's needed to point out that business is conducted, among other things, through contractual legal relationship, can be created by people individually or by a group of people having friends or family relationship.

\section{Results}

The need for interaction between the state, the personality and the business is discussed long enough [6]. Inheritance relations are surely linked with property relations. It's appropriate to indicate that following the traditions within the civilized doctrine the right of the property represents objectively an autonomous institution of the civil society, however, the property relations are believed to reveal comprehensive cross-sectoral nature, manifest themselves in entrepreneurial activity [7].

Under the doctrine, inheritance relations are considered to be determined as a set of interdependent relations aimed at the transfer of property consisting of the mass of succession from the deceased person, i.e. the estate-leaver, to his/her inheritors [8]. It is required to be perfectly aware that in case of the descent of business assets and entrepreneurial obligations the succession in inheritance, entrepreneur and family law is conditioned by the change of the identity of a person possessing a hereditary asset and is accompanied by the transfer of subjective rights and obligations from the estate-leaver to his/her inheritor. In this case, the family legal relationship does not end but persists as incorporated in a new subject. It is just a particular composition of entities based on relationship and properties of family relations that witnesses dual legal nature of inheritance institution by law: civil law institution and 
family law institution. Moreover, this law relationship can be complicated by entrepreneurial activity and business assets.

It is necessary to conclude that in Russia a definite business (company) shows its strong dependence on definite personalities who often created this one or hold leadership positions thereat. A frequent practice is so that when it deals with large companies, it's not the name of the company that is referred to but the name of its actual owner, its manager [9]. I.e., the company is merged with its owners at the household level.

As a result, the authors must state that, in fact, provisions of entrepreneurial and corporate law of the Russian Federation neglect the rights of the spouse-participant in common property in relation to the share in the statutory fund of a limited liability company that is acquired during the marriage from the common property of the spouses. Defining the procedure and features of transfer of the share to other persons arising from alienation, transfer of the share to inheritors of a physical person or to successors of a legal entity, applicable legislation does not envisage special regulations on the mechanism of transfer of the rights to the share in a limited liability company to a spouse of the company's participant. The authors suggest that in the case when there is a need to register the titles to the spouse share of a surviving spouse after the death of a company's participant one of the efficient variants of a practical solution for the given situation is to use provisions on transfer of the rights to inheritors as an analog of the law, however, taking into account particularities proper to spouses common property relationship, and excluding regulations that are applicable for succession only. At the same time, it's more preferable for the Law on economic companies to reflect the mechanism of transfer to the spouse of a part of the share of a limited liability company's participant.

\section{Discussion}

Following the idea of Professor G.F. Shershenevich a prerevolutionary civilist, legal relationship of a deceased person does not end upon his/her death but is transferred to his/her successors. A successor replaces a deceased participant in a legal relationship and shoulders all his/her obligations [10]. For the present, different legal families have a different understanding of the inheritance relations content. More specifically, in continental European countries, including Russia, there believe that fact of inheritance results in a universal succession and this is understandable.

The authors can assert with confidence that the rapid pace of development in social relations encourages complication of legal relationship formed between subjects of law, including inheritance relations. For the present, the legal status of the subject of inheritancelaw relationship is regularized not only by civil law but also by other related branches of law [11]. The goals of entrepreneurial relationship legal regulation, objectives to reach them and also principles as guidelines for the regulation of family business are prerequisites for publicization of entrepreneurial law as well as inheritance law and family [12]. "The State is entitled to delegate some of its powers to private entities, for example, when providing public services, carrying out certain acts, performing regulatory functions" [13].

The doctrine rightly remarks that the problem of inheriting a business as an insolvency estate is considered to be exacerbated by the "archaic nature" of our system of inheritance rights registration. Even though there is no one to struggle for a business, even though there is the sole inheritor, this one will be empowered to take control of the business only upon expiry of a 6-month period without regard to whatever circumstances. When this one find finally himself empowered, it often turns out that there is yet nothing to control [9].

As it is established in Article 1164 of the Civil Code of the Russian Federation, if inheritors' shares in the inherited property are not determined by the law or the testament, the inherited property becomes subject to shared ownership of all the inheritors. This regulation is as well applicable in the case of inheriting a business. Both inheritance-law 
relationship and family one are believed to largely arise from and be built on special legal facts based on family relationship. Family, civil, entrepreneurial and inheritance relations are interrelated owing to the unity of the domestic legal system [8].

The Federal Law No. 259-FZ "On amendment to the part one, two and three of the Civil Code of the Russian Federation" dated on the $29^{\text {th }}$ of July of (hereinafter referred to as FZ No. 259) legalizes the possibility to create a testamentary foundation in the framework of inheritance relations [14].

In the legal literature it's reasonably noted that the fact of obtention by a surviving spouse as a participant in spouses' common property of a part of the share in the statutory fund (authorized capital) of a limited liability company after the spouse's death does not represent the fact of inheritance [15-17].

\section{Conclusion}

It is argued that the possibility for the population to create testamentary foundations becomes important in line with the domestic public policies aimed at economic development and support of entrepreneurial activity among the population. Testamentary foundations will be able to ensure the most rapid and painless transfer of a business from the estate-leaver to the inheritors with minimum losses or even without these ones.

Nowadays the trend is to erase interbranch borders. The authors suppose that it would be more relevant to refer: public legal regulation and private legal regulation of entrepreneurial activity of the family members and business inheritance in the framework of their special legal regime of spouses' entrepreneurial activity. The authors witness a highly prominent convergence of private legal regulation and public legal regulation of inheritance relations complicated by the entrepreneurial activity of the family members. "Efficiency of interbranch links of the inheritance law must be built by excluding cases of failure to regulate appropriate legal relations that will allow speaking about optimization of interbranch links" [18].

It is required to point out that, when inheriting property, the status of a person as a surviving spouse involve the possibility for him/her to implement the rights arising from two types of legal relations: spouses' common joint property relations and property inheritance relations as in the majority of cases a surviving spouse is listed among inheritors (as the first in a line of inheritors by the law or as inheritor by the testament, or as a beneficiary of the obligatory share in inheritance). However, sometimes, when applying appropriate provisions of the law, the courts do not pay attention to the given circumstances justifying their decisions only by one scope of rights of a surviving spouse - as a spouse or as inheritor.

It is defined that domestic legislation in force in the field of inheritance relations does not take into account particularities of shares inheritance that results in considerable rights abuse of the very joint-stock company and other shareholders in the matter of protecting their legal interests in terms of inheritance relations.

\section{References}

1. A.A. Mokhov, A.N. Levushkin, A.N. Yavorsky, JARLE 11, 483-490 (2020). https://doi.org/10.14505/jarle.v11.2(48).21

2. A.N. Levushkin, O.V. Mitroshina, Notary 1, 32 (2014)

3. I.V. Ershova, E.E. Enkova, A.N. Levushkin, K.K. Dzhindzholiya, Project-based approach in training business lawyers for digital economy through the prism of goal setting, in Theory and Practice of Project Management in Education: Horizons and Risks, ISAPC, 17 April, 2020, Moscow, Russia (2020). https://doi.org/10.1051/shsconf/20207901005 
4. A.A. Mohov, Med. Law 1, 6 (2016)

5. A.N. Levushkin, I.V. Zaikina, M.A. Bulavina, G.A. Kozlitin, V.V. Zaikin, PalArch's J. of Arch. of Egypt 17, 6964-6973 (2020)

6. A.N. Levushkin, J. of Entrepreneurial and Corp. Law 3, 15 (2016)

7. A.N. Levushkin, A.A. Vlasov, T.E. Rakhmatullin, L.E. Rakhmatullina, Opcion, 35, 721-736 (2019)

8. A.N. Levushkin, M.I. Babich, Inheritance Law, 2, 10-14 (2018)

9. V.A. Belov, B. Econ, Justice of the Russ. Federation 7, 130-147 (2015)

10. G.F. Shershenevich, Uchebnik grazhdanskogo prava [Manual of the Russian civil law], vol. 2 (Spark, Moscow, 1995)

11. Y.G. Leskova, Inheritance Law, 1, 13 (2017)

12. Y.G. Leskova, A.N. Levushkin, S.Yu. Morozov, V.V. Romanov, S.G. Poberezhny, L.E. Rakhmatullina, Int. J. Econ. \& Business Adm. 3, 700-709 (2020).

https://doi.org/10.35808/ijeba/620

13. V.V. Kudryashov, Finan. Law 11, 6-9 (2015)

14. M.A. Kartashov, Mod. Law 10, 83-90 (2017)

15. M.N. Iljushina, Prava suprugov na dolyu v obshhestve s ogranichennoj otvetstvennostyu: problemy perekhoda i oformleniya [Spouses' rights to a share in a limited liability company: problems of transfer and registration], in I.V. Ershova, A.N. Levushkin (eds.), Semejnyj biznes v pravovom prostranstve Rossii [Family business in the Russian legal space] (Prospekt, Moscow, 2020).

https://doi.org/10.31085/9785392299539-2020-624

16. S.Ju. Chashkova, Russ. Law: Experience, Analysis, Practice 4, 30-36 (2018)

17. A.A. Serebrjakova, Inheritance Law, 2, 23-25 (2018)

18. Y.G. Leskova, Inheritance Law, 1, 11-13 (2017) 